\title{
CONTESTATION BETWEEN STATE LAW AND ISLAMIC LAW IN LEGAL PRACTICES AMONG INDONESIAN MUSLIMS
}

\author{
Nabiela Naily \\ IAIN Sunan Ampel, Surabaya - Indonesia
}

Book Review

\begin{tabular}{|c|c|c|}
\hline 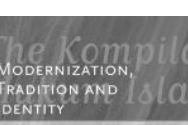 & Book title & $\begin{array}{l}\text { Modernization, Tradition and Identity; The } \\
\text { Kompilasi Hukum Islam and Legal Practice in the } \\
\text { Indonesian Religious Courts }\end{array}$ \\
\hline 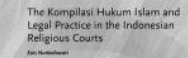 & Author & : Euis Nurlaelawati \\
\hline & No. of Pages & : 297 \\
\hline & Year & : 2010 \\
\hline 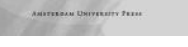 & Publisher & : ICAS/ Amsterdam University Press \\
\hline
\end{tabular}

One of the main issues in the Islamic world is the relation between state and Islamic law. The common problem is the contestation between the existing Islamic law living in the society and the laws the government or the state tried to impose upon its citizens. The question on what law Muslims actually adhere in a country, usually countries where Muslims are the majority population including Indonesia, is always a big questions among legal scholars. This book by Euis Nurlaelawati, is one of a very few books attempting to answer that question for Indonesian case.

The book targets directly the 1991 Kompilasi Hukum Islam, commonly known and abbreviated as KHI, since it is seen as one key issue described very clearly in the preface of the book as 'from fiqh to a systematised legal code'. Presumably, KHI must be used by judges of Religious Court across Indonesia as legal consideration in hearing family cases. Here, the intention of the author is to answer the frequently asked question by the Islamic legal scholars in Indonesia; 
what Islamic family law actually is upheld by the Indonesia Muslims, State law, here represented by the Kompilasi, or the figh (Islamic Jurisprudence). ${ }^{1}$ In doing so, the author tries to answer the research question by looking at the legal practices among the judges of the religious courts in several cities in West Java region and Jakarta. In addition, she also looks at the legal practices among the Indonesian Muslims related to family affairs.

The first chapter of the book analyzes the historical dynamics of the religious courts in Indonesia. In this chapter, the author shows that Indonesian religious courts, which mainly hear family cases, have undergone many phases traced back from the earliest era when Islam came to the Archipelago. Initially, the court took form as a tabkim (a kind of arbitration), very informal, then took to a more formal shape with a qadi (Muslim judge) appointed by Ulama, and then followed by more formal institutions named as Pengadilan Agama (Religious Court) in many sultanates in the archipelago. These forms of religious courts continued to the period of the Dutch colonialization with several adjustments and restrictions to colonial master's flavor and then brief Japanese occupation.

During pre-colonial period, the existence of the religious courts is said to have great influence to the earliest efforts by some Muslim Scholars to compose figh books and or establish a standard manual book by translating Arabic fiqh books to the Malay language and further adding some commentaries. In this chapter, the author also succeeds in showing the dynamics of the contestation between the Dutch authority and the indigenous Muslim population in relation to the application of the law concerning family cases. It shows the divergent Dutch's attitudes toward Islamic law as it happened in colonial territories. Colonial masters, the Dutch in this case, initially imposed western law by ignoring Islamic legal tradition that lived on the ground.

This policy was doomed to failure since it was instantly rejected by local Muslim population. The Dutch then tried to accredit Islamic law but gradually reduce the authority and scope Islamic law by reducing the competence of the religious courts. Among the policy to reduce

\footnotetext{
${ }^{1}$ Why family law? This is because family law is the one area where figh are still upheld so strictly by many muslims all around the world. That is why contestation between the state and the fiqh remains an issue while such thing does not occur in the area of the penal law.
} 
the competence of religious courts was that all decisions of Religious Courts, which then limited only in the area of family cases did not have legal effect until enforced by the Civil Court. This situation continued until Indonesia proclaimed its independence in 1945.

The following two chapters offer the history on the making of the Kompilasi Hukum Islam (KHI) and the debates surround the process especially in several controversial issues. Here, the author succeeds in providing not only very informative accounts regarding the making of Kompilasi, but also the dynamics of the political aspect that indeed cannot be separated from this issue. It argues that the shifting of the Suharto's political attitudes towards Islam and Muslims in Indonesia starting in 1990s indeed is vital in the success of the making of the Kompilasi. Furthermore, it also describes the debates surround some sensitive issues such as inheritance, polygyny and other issues. The Ulama, the state as well as women activists are desribed as agents that actively heated the debate. In sum, there are some compromises and in fact some open-interpretable elements in the Kompilasi that, as will be explained later, becomes one of the sources of the problems of the acceptance of the Kompilasi by Indonesian Muslims.

It is in the following three chapters, chapter four, five and six, the author attempts to answer the main question of the study. She first argues that the judges of religious courts, both from interviews and from court decisions, still show reluctance to rely merely on the Kompilasi as legal basis of decision.

The author offers two evidences; first is that the judges still quote figh in their court decisions, and second is the fact that some judges indeed explicitly express some reservations on the authority of the Kompilasi. The author also gives some examples where judges, either quoting fiqh or to even more radical deviating from the stipulation of the Kompilasi. The second case mostly happen in sensitive issues in which the kompilasi regulates quite differently from the figh such as inheritance.

This explanation is then followed by the analysis on the reasons and factors contributing to such trend. They range from the legal status of the Kompilasi as a Precidential Instruction (INPRES), which is less binding than a law, to a more intrinsic reason such as judge's beliefs that the Kompilasi is less authoritative than figh. Furthermore, the Kompilasi lacks of religious justification because the judges believe that the Kompilasi is mixed with the adat (customary) law which is not 
Islamic. There is also perception that the Kompilasi, as a product of the state, is not adequate in regulating certain religious matters. Some judges also assert that ijtihad (individual legal finding) is one primary task of the judge that is not facilitated by the Kompilasi and so forth.

Based on these findings, the author conclude that the kompilasi has failed in its mission to be an Indonesian version of Islamic law. After arguing the 'failure of the Kompilasi' in being the only legal reference among the judges of the religious courts, the last chapter tries to show the variety and the trend of legal practices among the Muslim society, not the judges, in relation to family cases. In sum, the author argues that the kompilasi is not yet being the reference for Indonesian Muslims in their family matters. Some evidences are the high incidence of unregistered marriages, the divorce outside the court, inheritance and so forth.

Furthermore, the author also argues that in most cases, Indonesian Muslims actually still rely on ulama in asking for fatwa (non-binding legal opinion) in their family problems and go to the religious courts merely for legalization of the already settled things. In conclusion, the author emphasizes the main argument saying that the Kompilasi which is aimed at setting a uniformity in legal reference for legal practices in Indonesia has not yet achieve that goal. This is illustrated in the legal practices of the judges of the religious courts and within the society.

Having outlined the content of this book, admittedly it contributes several things to the study of Islamic law in contemporary Indonesia. There are many strengths of the book that makes it very worthy especially for the legal scholars and practitioners. Consisting of 297 pages, the book discusses the issue about Kompilasi Hukum Islam in such deep, focused and comprehensive exploration and analyses. The coverage is quite extensive, which is not so surprising, because the book is based on a Ph.D dissertation research of the author. Extensive fieldwork within the areas of West Java and Jakarta, in addition to extensive documentations analyses, have resulted in the vast array of accounts that give the audience not only feelings of interested but also offer validity and accuracy in depicting the phenomenon.

Moreover, not only discussing the Kompilasi from legal-empirical perspectives, the book also depicts political aspects leading to its inception especially in regard to the issue of Islam-state relation that offers readers added values. One good example how the author even succeeds in depicting very small yet important detail is when she shows 
the political strategy used by Bustanil Arifin, the project coordinator of the Kompilasi, in proposing the Kompilasi project to the President at the time, Suharto. As known, the New Order Regime under Suharto was authoritarian and politically repressive. Intelligently, Bustanul Arifin using Suharto's fear towards the unpredictable variety of views among Indonesian Muslims and argues the importance of the Kompilasi as it is aimed to be the uniform legal reference.

Another strength of the book is the historical account and logical flow of information that is organized very smoothly that can give the readers both information and joyful reading. The author sketches the period starting from the establishment of the religious courts in precolonial period until post-independence period when the Kompilasi is incepted. This account is enriched with the issues surrounding the debates between Islam and politics which succeeds in giving audience feeling of the significance of the issue. The main argument that is illustrated from the attitudes of the judges and society also is one strength. Focusing on hundreds of legal documents is also a good choice. As Durkheim noted, a legal document "represents a bringing together of socially constituted and enduring legal principles with individually constituted and ad hoc negotiated terms."

However, in spite of many strengths mentioned earlier, there are also several minor flaws of the book. One of the main critics is that the author fails to give proportional discussion on the roles of the women activism in shaping the discourse in the making of the 1973 bill and the subsequent 1974 Marriage Act. Such attitude actually undermines the historical role played by women activists in the shaping of the marriage law in Indonesia. In addition, even though the use of the theories are very useful and have been stated clearly in the beginning of the book, the employment of the theories are not very sharp especially in supporting the analysis of data available that eventually will lead to strengthen the argument.

Throughout the book, the mention of the theories let alone their employment in the analysis is relatively poor. Meanwhile, more use of theory of the function of law as a mechanism for social change can make the analysis even deeper. Another thing is that a researcher cannot merely rely on the interviewees' responses without being skeptical about it. To take one example, the author seems to accept the judges' answers in case of the influence of adat law in the Kompilasi without considering the other more important aspect that is the 
influence of other Islamic schools of law (Madz̧ab) such as Hanafi in the Kompilasi. Consequently, issue on the variety of mazhab is not apparent in the book while it is indeed an important factor in shaping the judge's attitudes. Admittedly, the author in several cases shows her critiques and sharp analysis on the judge's answers but unfortunately not on the issue of the variety of the mazhab.

The author also seems to fail give adequate account concerning the reason behind harsh attitude of mainly Dutch colonial master toward Islamic law. This explanation, which originated from Muslims stiff resistance toward the Dutch presence in the archipelago as shown by series of revolts by Muslims, would illuminate several puzzles surrounding the Dutch policies in East Indies Indonesia.

Nevertheless, despite the mentioned flaws, the book is indeed very informative and contributive. Any person who wants to know and comprehend all aspects and issues related to the Kompilasi Hukum Islam along with the relevant issues in Indonesia will find the book very helpful. Furthermore, the book also opens minds of all law scholars the possible future researches such as a research in issue of RUU HMPA (bill on Religious Court substantive law) and the MK (Constitutional Court) decree that re-show the classic issue that is the problem of the contestation between the state law and the existing fiqih and adat law among the Muslims in Indonesia. At last, the question on how the law can actually functions as a tool for social changes and or a question on to what extent the state can intervene in religious practices or private sphere is indeed very intriguing. [] 